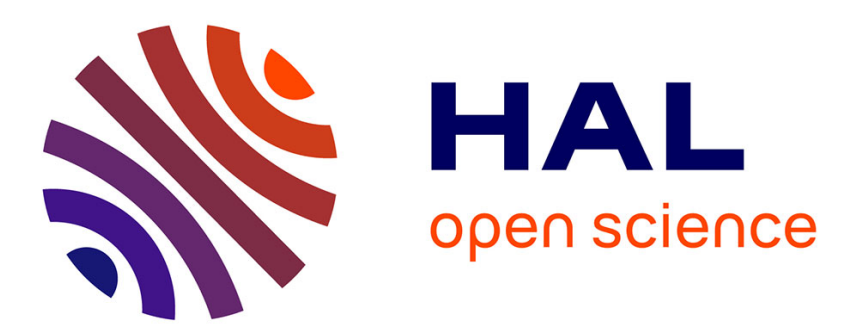

\title{
Use of the MicroResp method to assess pollution-induced community tolerance to metals for lotic biofilms
}

Ahmed Tlili, Marjorie Marechal, Bernard Montuelle, Bernadette Volat, Ursula Dorigo, Annette A. Berard

\section{To cite this version:}

Ahmed Tlili, Marjorie Marechal, Bernard Montuelle, Bernadette Volat, Ursula Dorigo, et al.. Use of the MicroResp method to assess pollution-induced community tolerance to metals for lotic biofilms. Environmental Pollution, 2011, 159 (1), pp.18-24. 10.1016/j.envpol.2010.09.033 . hal-01319975

\section{HAL Id: hal-01319975 \\ https://hal.science/hal-01319975}

Submitted on 29 May 2020

HAL is a multi-disciplinary open access archive for the deposit and dissemination of scientific research documents, whether they are published or not. The documents may come from teaching and research institutions in France or abroad, or from public or private research centers.
L'archive ouverte pluridisciplinaire HAL, est destinée au dépôt et à la diffusion de documents scientifiques de niveau recherche, publiés ou non, émanant des établissements d'enseignement et de recherche français ou étrangers, des laboratoires publics ou privés. 


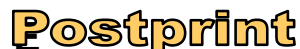

Version définitive du manuscrit publié dans / Final version of the manuscript published in : Environmental Pollution, 2011, Vol.159, no.1, 18-24, DOI: 10.1016/j.envpol.2010.09.033

1 Use of the MicroResp ${ }^{\mathrm{TM}}$ method to assess pollution-induced community

2 tolerance to metals for lotic biofilms

3

4 Ahmed Tlili ${ }^{\mathrm{a}}$, Marjorie Marechal ${ }^{\mathrm{a}}$, Bernard Montuelle ${ }^{\mathrm{a}}$, Bernadette Volat ${ }^{\mathrm{a}}$, Ursula $5 \quad$ Dorigo $^{\mathrm{b}}$, Annette Bérard ${ }^{\mathrm{c}}$

6

7 a. CEMAGREF, UR MAEP, 3 quai Chauveau CP 69336 Lyon Cedex 09, France

8 b. INRA UMR CARRTEL, Laboratoire de Microbiologie Aquatique, BP 511, 74203, Thonon 9 Cedex, France

10 c. INRA UMR CSE-EMMAH 1114, Domaine Saint-Paul - Site Agroparc 84914 Avignon 11 Cedex 9, France

13 Corresponding author (Tlili, A.):

14 Tel.+33472208912; Fax.+33478477875 ; e-mail. ahmed.tlili@cemagref.fr

15 Other e-mail addresses:

16 marjorie.marechal@,cemagref.fr

17 bernard.montuelle@cemagref.fr

18 bernadette.volat@cemagref.fr

19 ursula.dorigo@thonon.inra.fr

20 annette.berard@avignon.inra.fr

\section{Abstract}

22 Understanding the ecological status of aquatic ecosystems and the impact of anthropogenic 23 contamination requires correlating exposure to toxicants with impact on biological 24 communities. Several tools exist for assessing the ecotoxicity of substances, but there is still a 


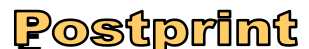

Version définitive du manuscrit publié dans / Final version of the manuscript published in : Environmental Pollution, 2011, Vol.159, no.1, 18-24, DOI: 10.1016/j.envpol.2010.09.033

25 need for new tools that are ecologically relevant and easy to use. We have developed a 26 protocol based on the substrate-induced respiration of a river biofilm community, using the

27 MicroResp ${ }^{\mathrm{TM}}$ technique, in a pollution-induced community tolerance approach. The results 28 show that MicroResp ${ }^{\mathrm{TM}}$ can be used in bioassays to assess the toxicity toward biofilm 29 communities of a wide range of metals $(\mathrm{Cu}, \mathrm{Zn}, \mathrm{Cd}, \mathrm{Ag}, \mathrm{Ni}, \mathrm{Fe}, \mathrm{Co}, \mathrm{Al}$ and $\mathrm{As})$. Moreover, a 30 community-level physiological profile based on the mineralization of different carbon 31 substrates was established. Finally, the utility of MicroResp ${ }^{\mathrm{TM}}$ was confirmed in an in-situ 32 study showing gradient of tolerance to copper correlated to a contamination gradient of this metal in a small river.

Capsule: A modified MicroResp ${ }^{\mathrm{TM}}$ technique as a tool for measuring induced tolerance to heavy metals of microbial biofilm community.

Keywords: river biofilm; pollution-induced community tolerance; substrate induced respiration; heavy metals; MicroResp ${ }^{\mathrm{TM}}$. 


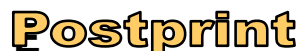

Version définitive du manuscrit publié dans / Final version of the manuscript published in : Environmental Pollution, 2011, Vol.159, no.1, 18-24, DOI: 10.1016/j.envpol.2010.09.033

\section{Introduction}

In a setting of agricultural land use, small lotic ecosystems (Strahler order below 3) are very sensitive to pollution because of generally low dilution and contiguous contamination sources (spraying of pesticides, run off...) (Dorigo et al., 2003). In these ecosystems, biofilms (attached microbial communities of autotrophic and heterotrophic, eukaryotic and prokaryotic populations) play a fundamental role in the aquatic trophic web and geochemical cycles (Battin et al, 2003). In agricultural watershed rivers, biofilms are exposed directly to toxicants that run off from fields, and their structure and function can be affected. The vast diversity of microbial species and the multitude of biological and physico-chemical processes induce a large structural and functional complexity into the matrix biofilm. Also, species composing the biofilm may have ranging sensitivities and responses towards various anthropogenic pressures (Barranguet et al., 2003). During exposure to toxic agents such as heavy metals, the most sensitive organisms may be overtaken by more resistant or more tolerant ones. Thus the entire community may be restructured, present physiological alterations and come finally to display an overall increase in tolerance to the toxicant. This process underlies the concept of pollution-induced community tolerance (PICT), developed by Blanck et al. (1988) as an ecotoxicological tool to assess xenobiotic impact at the community level.

Diverse approaches to examining the tolerance or resistance of a bacterial community to heavy metals have been developed. For example, Díaz-Raviña et al. (2007) investigated vineyard soil copper contamination inducing bacterial tolerance with growth measurements using thymidine (Tdr) and leucine (Leu) incorporation techniques. In aquatic systems Tdr or Leu incorporation techniques have also been used to assess the tolerance of bacterial communities in biofilm and sediments (Paulsson et al., 2000; Lesley and Grant, 2007). Despite good results, these techniques remain difficult to implement and are not possible in all laboratories as they use radio-labelled elements. Biolog ${ }^{\mathrm{TM}}$ is a conventional approach applied first to obtain catabolic fingerprints of the bacterial communities or a community- 


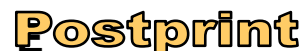

Version définitive du manuscrit publié dans / Final version of the manuscript published in : Environmental Pollution, 2011, Vol.159, no.1, 18-24, DOI: 10.1016/j.envpol.2010.09.033

level physiological profile (CLPP), and more recently to assess tolerance to metals of the bacterial communities in soil and aquatic biofilms (Boivin et al., 2006; Stefanowicz et al., 2009). However, this microplate technique, based on the analysis of a bacterial community's use of several carbon sources, has major drawbacks: incomplete assessment of the whole microbial community, a long incubation time inducing bacterial selection and growth (Preston-Mafham et al., 2002) and the use of artificial culture media with buffer that may have artificial significant effects on the speciation and in consequence on the bioavailability and the toxicity of toxicants (Barranguet et al. 2003). A respirometric technique based on the analysis of the substrate-induced respiration (SIR) response (using gas chromatography analysis) was also investigated with a multiple carbon-source substrate for CLPP (Garland and Mills, 1991), and in a few studies, to test microbial tolerance to heavy metals at the community level in soils (Witter et al., 2000; Rajapaksha et al., 2004). More recently this approach was used to assess induced tolerance to copper of bacterial communities in river biofilms (Tlili et al., 2010). However, the method is still tedious, especially when assaying many microbial samples simultaneously in a multitude of bottles that have to be processed separately to measure the amount of released $\mathrm{CO}_{2}$ (Chapman et al., 2007). Miniaturized systems offer the considerable advantage of allowing sample and replicate multiplication. In soil studies, Campbell et al. (2003) developed the MicroResp ${ }^{\mathrm{TM}}$ technique, which is an alternative method that combines the advantages of the Biolog ${ }^{\mathrm{TM}}$ technique, using the microplate system, and of the SIR approach with ability to measure $\mathrm{CO}_{2}$ production during short-term incubation from a whole soil microbial community.

We hypothesized that the use of this new microrespirometric technique could be modified and applied to perform ecotoxicological bioassays on river biofilms for metal tolerance comparison purposes. The objectives of our study were thus (i) to test the MicroResp ${ }^{\mathrm{TM}}$ technique for a metal-contamination assessment in an aquatic ecosystem, using biofilms as a biological model in a PICT approach, (ii) to take a catabolic fingerprint of the heterotrophic 


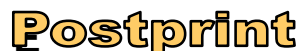

Version définitive du manuscrit publié dans / Final version of the manuscript published in : Environmental Pollution, 2011, Vol.159, no.1, 18-24, DOI: 10.1016/j.envpol.2010.09.033

101 biofilm community, and (iii) to implement an in-situ PICT application of MicroResp ${ }^{\mathrm{TM}}$ in a

102 copper contamination context.

\section{II. Materials and methods}

\section{In-situ biofilm}

105 The biofilm used in our study was taken from the River Morcille, located in the Beaujolais vineyard area. The Morcille is a small first-order stream $(7 \mathrm{~km}$ long) under strong agricultural pressure, essentially from vineyards, which occupy about $80 \%$ of its $8.5 \mathrm{~km}^{2}$ catchment area. The Morcille watershed is part of the Long-Term Ecological Research Rhône Basin (ZABR).

109 Regular physico-chemical surveys (hydrology, nutrients, pesticides and metals) and biological monitoring have been conducted on this site (Dorigo et al., 2007; Rabiet et al., 2008; Morin et al., 2010; Montuelle et al., 2010). Three sampling sites were selected along a gradient of increasing percentage contribution of vineyards to the catchment area: Saint-Joseph (vineyard percentage cover $11 \%$ ), Les Versauds (53\%) and Saint-Ennemond (65\%) (see Table. 1 for physico-chemical details). Several annual surveys were performed to characterize metal contamination. In 2009 ( $n=43$ samples), Saint-Joseph was the least polluted site with a mean $0.51 \pm 0.02 \mu \mathrm{g} . \mathrm{L}^{-1}$ of $\mathrm{Cu}, 1.13 \pm 0.21 \mu \mathrm{g} . \mathrm{L}^{-1}$ of $\mathrm{Zn}$ and $1.94 \pm 0.46 \mu \mathrm{g} . \mathrm{L}^{-1}$ of As. By contrast, the two other sites studied were considered polluted: Les Versauds was characterized by a 118 mean $2.05 \pm 0.25 \mu \mathrm{g} . \mathrm{L}^{-1}$ of $\mathrm{Cu}, 0.83 \pm 0.42 \mu \mathrm{g} . \mathrm{L}^{-1}$ of $\mathrm{Zn}$ and $11.5 \pm 0.46 \mu \mathrm{g} . \mathrm{L}^{-1}$ of As, and Saint-Ennemond by a mean $3.93 \pm 0.77 \mu \mathrm{g} \cdot \mathrm{L}^{-1}$ of $\mathrm{Cu}, 7.05 \pm 3.56 \mu \mathrm{g} . \mathrm{L}^{-1}$ of $\mathrm{Zn}$ and 9.26 $\pm 4.99 \mu \mathrm{g} . \mathrm{L}^{-1}$ of As. Other metals including $\mathrm{Cd}, \mathrm{Ni}, \mathrm{Fe}$ or $\mathrm{Al}$ were also detected at low levels (means near limits of quantification) and there was no gradient of contamination from 122 upstream to downstream.

123 Table. 1

\section{2. Biofilm microcosm}




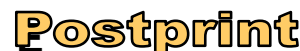

Version définitive du manuscrit publié dans / Final version of the manuscript published in : Environmental Pollution, 2011, Vol.159, no.1, 18-24, DOI: 10.1016/j.envpol.2010.09.033

125 During the different experiments with the MicroResp ${ }^{\mathrm{TM}}$, a biofilm was grown on artificial 126 substrates (microscope slides previously cleaned in a dilute nitric acid bath and rinsed with milli-Q water before use) in laboratory microcosms under controlled conditions. Fifteen-litter aquariums were filled with river water from the reference site (Saint-Joseph), which had been filtered through a $50 \mu \mathrm{m}$ mesh to remove most of the grazers (water was renewed once a week). The water was kept at a temperature of $18 \pm 2{ }^{\circ} \mathrm{C}$, and exposed to a light intensity of $260 \mu \mathrm{mol} \mathrm{m} \mathrm{m}^{-2}$, with a light/dark regime of 18:6 h. Three-week-old biofilms were used for the MicroResp ${ }^{\mathrm{TM}}$ assays (Tlili et al., 2008).

\section{The MicroResp ${ }^{\mathrm{TM}}$ procedure}

134 MicroResp $^{\mathrm{TM}}$ system has been described in detail by Campbell et al. (2003), but only a few 135 ecotoxicological applications of the MicroResp ${ }^{\mathrm{TM}}$ technique have been investigated on soils (Kaufmann et al. 2006) and none on aquatic microbial communities. Here we present an adaptation of the procedure of Campbell et al. (2003) to aquatic biofilm suspensions and toxicological bioassays. MicroResp ${ }^{\mathrm{TM}}$ is a colorimetric method based on the colour change of a $\mathrm{pH}$ indicator dye caused by the release of $\mathrm{CO}_{2}$ by heterotrophic communities. The system consists of two microplates (96 wells) placed face to face. One of these is a deep-well microplate (1.2 mL capacity, 96-deep-well microplate, NUNC) in which each well contains the microbiological sample (we used a $500 \mu \mathrm{L}$ biofilm suspension obtained by scraping biofilm off glass substrata using a polypropylene spatula and suspending it in $0.2 \mu \mathrm{m}$ of Nuclepore-filtered water from the reference site) with the carbon source ( $30 \mu \mathrm{L}$ per well, 6.2 mg of $\mathrm{C}$ per well). To this deep-well microplate we added the toxicant (50 $\mu \mathrm{L}$ per well). The second microplate contained the detection gel (cresol red dye (12.5 ppm), potassium chloride $(150 \mathrm{mM})$ and sodium bicarbonate $(2.5 \mathrm{mM})$ set in a $1 \%$ gel of noble agar (final volume 150 $\mu \mathrm{L}$ per well)). The two microplates were sealed together with a silicone seal, with interconnecting holes between the corresponding wells. The assembly was clamped together and the system was incubated in the dark (to avoid any photosynthesis interference with $\mathrm{CO}_{2}$ 


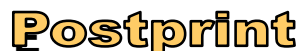

Version définitive du manuscrit publié dans / Final version of the manuscript published in : Environmental Pollution, 2011, Vol.159, no.1, 18-24, DOI: 10.1016/j.envpol.2010.09.033 release) at room temperature. $\mathrm{CO}_{2}$-trap absorbance was measured at $590 \mathrm{~nm}$ (Biotek Synergy

HT spectrophotometer) immediately before sealing to the deep-well plate (coefficient of variation below 5\%), and after incubation. Quantities of $\mathrm{CO}_{2}$ produced by the microbial samples were calculated using a calibration curve of absorbance values versus $\mathrm{CO}_{2}$ quantity measured by gas chromatography (MTI 200 microcatharometer). Results were then expressed as $\mu \mathrm{g} \mathrm{CO}_{2} \cdot \mathrm{mg}^{-1}$ of sample. $\mathrm{h}^{-1}$. In our biofilm study, the sample was considered as organic matter (ash-free dry weight, AFDW) of the biofilm suspension tested, and measured using the protocol described by Tlili et al. (2008). Briefly, three aliquots of each homogenized biofilm suspension $(2 \mathrm{~mL})$ were filtered through individual $25 \mathrm{~mm} \mathrm{CF} / \mathrm{C}$ Whatman glass fibre filters (1.2 $\mu \mathrm{m}$ pore size). Total dry matter was measured by weighing the filters after drying at $105^{\circ} \mathrm{C}$ for $24 \mathrm{~h}$. The filters were then combusted in an oven at $480^{\circ} \mathrm{C}$ (Nabertherm P320) for $1 \mathrm{~h}$, and reweighed to calculate mineral matter. AFDW was calculated by subtracting mineral matter from total dry matter.

\section{Development of the MicroResp ${ }^{\mathrm{TM}}$ protocol}

Table. 2

\subsection{Incubation time}

Campbell et al. (2003) propose an incubation time of $6 \mathrm{~h}$ with soil samples. However, in our case, we have to take into account the rate of $\mathrm{CO}_{2}$ diffusion at the air-water interface, which may be low. To ensure a relevant measure in the well airspace of the $\mathrm{CO}_{2}$ released from the sample (the biofilm), we tested a range of incubation times: $4,6,8$, and $15 \mathrm{~h}$. Individual MicroResp $^{\mathrm{TM}}$ microplates were used for each incubation time. Eight deep wells of each microplate were filled with $500 \mu \mathrm{L}$ of biofilm suspension with $50 \mu \mathrm{L}$ of milli-Q water and 30 $\mu \mathrm{L}$ of D-glucose (Prolabo) (the remaining wells of the microplate were filled with $580 \mu \mathrm{L}$ of milli-Q water). Quantities of released $\mathrm{CO}_{2}$ were measured at each incubation period, as described in Section 3.

\subsection{Pre-incubation test with toxicant}




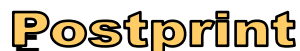

Version définitive du manuscrit publié dans / Final version of the manuscript published in : Environmental Pollution, 2011, Vol.159, no.1, 18-24, DOI: 10.1016/j.envpol.2010.09.033

177 To enable the toxicant to penetrate into the cells and to cope with artefacts causing a chemical 178 release of $\mathrm{CO}_{2}$ (Lindsay, 1979), a metal pre-exposure period was necessary before adding the carbon substrate (glucose) and starting the incubation. The different tested times of preexposure to $\mathrm{Cu}$ were $0,0.25,0.5,1,2,3,4$ and $6 \mathrm{~h}$.

\subsection{Short-term bioassays}

182 To validate the utility of the MicroResp ${ }^{\mathrm{TM}}$ method for short-term bioassays, using biofilms, a 183 wide range of heavy metals was tested: $\mathrm{CuSO}_{4}$ (Merck $\mathrm{KgaA}$; purity $\geq 99.0 \%$;), $\mathrm{ZnSO}_{4}$ 184 (Sigma-Aldrich $\mathrm{GmbH}$ ), $\quad \mathrm{CdN}_{2} \mathrm{O}_{6} \cdot 7 \mathrm{H}_{2} \mathrm{O}$ (Fluka Sigma-Aldrich; purity $\geq 99.0 \%$ ), $\mathrm{AgNO}_{3}$ (CARLO ERBA reagenti; purity $\geq 99.8 \%$ ), $\mathrm{N}_{2} \mathrm{NiO}_{6} \cdot 6 \mathrm{H}_{2} \mathrm{O}$ (Fluka Sigma-Aldrich Chemie $\mathrm{GmbH}$; purity $\geq 97.0 \%$ ), $\mathrm{FeSO}_{4} .7 \mathrm{H}_{2} \mathrm{O}$ (Sigma Chemical co.; purity $\geq 99.0 \%$ ), $\mathrm{CoN}_{2} \mathrm{O}_{6} \cdot 6 \mathrm{H}_{2} \mathrm{O}$

187 (Fluka Sigma-Aldrich Chemie $\mathrm{GmbH}$; purity $\geq 98.0 \%$ ), $\mathrm{AlN}_{3} \mathrm{O}_{9} .9 \mathrm{H}_{2} \mathrm{O}$ (Merck KgaA; purity $\geq 98.5 \%$ ) and $\mathrm{Na}_{2} \mathrm{HAsO}_{4} .7 \mathrm{H}_{2} \mathrm{O}$ (Sigma-Aldrich $\mathrm{GmbH}$; purity $\geq 98.0 \%$ ). Briefly, stock solutions containing $200 \mathrm{mM}$ of each metal were prepared in water and stored at $4{ }^{\circ} \mathrm{C}$, before dilution in the test wells. A semi-logarithmic series of concentrations was freshly prepared by serial dilution of the stock solutions in $0.2 \mu \mathrm{m}$-filtered river water. Final nominal test concentrations in the deep wells ranged from $0.5 \mu \mathrm{M}$ to $17.2 \mathrm{mM}$ ( 4 blanks and 4 replicates for each of the 9 concentrations). The carbon substrate used for all the SIR toxicological bioassays was D-glucose. Quantities of released $\mathrm{CO}_{2}$ were measured for each bioassay as described in Section 3. Dose-response curves were plotted using $\mathrm{CO}_{2}$ values produced by biofilm at each metal concentration as a percentage of $\mathrm{CO}_{2}$ produced by a control biofilm 197 (without toxicant).

\section{Application of the microrespirometric method to a field situation}

\subsection{PICT approach (short-term bioassays)}

The relevance of the MicroResp ${ }^{\mathrm{TM}}$ technique in a PICT approach was tested with biofilms sampled from the River Morcille. Induced tolerances to $\mathrm{Cu}, \mathrm{Cd}$ and $\mathrm{Ag}$ of the heterotrophic biofilm communities were then tested by toxicological bioassay using the MicroResp ${ }^{\mathrm{TM}}$ 


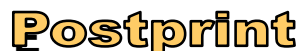

Version définitive du manuscrit publié dans / Final version of the manuscript published in : Environmental Pollution, 2011, Vol.159, no.1, 18-24, DOI: 10.1016/j.envpol.2010.09.033

method. Briefly, biofilms were scraped from stones $\left(500 \mathrm{~cm}^{2}\right.$ per sample) collected from the

three sampling sites described previously (St. Joseph (J), Les Versauds (V) and Saint-

Ennemond (E)), and homogenized in $150 \mathrm{~mL}$ of $0.22 \mu \mathrm{m}$-filtered water from the reference site (J). Biofilm suspensions were placed directly in the deep well $(500 \mu \mathrm{L})$ and $50 \mu \mathrm{L}$ of each tested metal $(\mathrm{Cu}, \mathrm{Cd}$ or $\mathrm{Ag})$ was added separately. After pre-incubation $30 \mu \mathrm{L}$ of glucose was added to each of the deep wells, and the MicroResp ${ }^{\mathrm{TM}}$ system was assembled as described previously and incubated in the dark at room temperature $\left(23 \pm 1{ }^{\circ} \mathrm{C}\right)$. After incubation, the absorbance of the detection microplate was measured at $590 \mathrm{~nm}$ (Biotek Synergy HT spectrophotometer), the amounts of released $\mathrm{CO}_{2}$ were calculated and the results were expressed in $\mu \mathrm{g} \mathrm{CO}_{2} \cdot \mathrm{mg}^{-1} \mathrm{AFDW} \cdot \mathrm{h}^{-1}$. Dose-response curves were plotted using $\mathrm{CO}_{2}$ values produced by the biofilm at each metal concentration as a percentage of the $\mathrm{CO}_{2}$ produced by control biofilms (without toxicant). The $\mathrm{EC}_{50}$ values were calculated for each metal and for each site.

\subsection{Catabolic diversity fingerprint}

With a view to establishing a CLPP of the heterotrophic biofilm compartment, a multiple carbon-source substrate-induced respiration approach (using the MicroResp ${ }^{\mathrm{TM}}$ technique) was used. The different carbon substrates used were: D-glucose (Prolabo), D-fructose (Sigma chemical Co.), D-sucrose (Fluka biochemica), D-ribose (Prolabo), D-galactose (Prolabo), Dmaltose (Prolabo), L-arginine (Sigma Chimie Fluka), glycine (Sigma Aldrich Chemie), Llysine hydrochloride (Sigma Chimie, Fluka), L-glutamic acid (Sigma Aldrich Chemie) and citric acid anhydre (Sigma Aldrich Chemie). Stock solutions containing $120 \mathrm{mg} \cdot \mathrm{mL}^{-1}$ of each substrate were prepared in $0.22 \mu \mathrm{m}$-filtered Milli Q water and stored at $4{ }^{\circ} \mathrm{C}$, until used. The $\mathrm{pH}$ of each solution was adjusted to river $\mathrm{pH}(7)$ to prevent any substrate- $\mathrm{pH}$ effects on microbial communities and minimize chemical artefacts due to carbonate-derived $\mathrm{CO}_{2}$. Final concentration was $6.2 \mathrm{mg}$ of $\mathrm{C}$ per $\mathrm{mL}$ in each deep well. The results were expressed in $\mu \mathrm{g}$ 


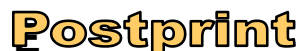

Version définitive du manuscrit publié dans / Final version of the manuscript published in : Environmental Pollution, 2011, Vol.159, no.1, 18-24, DOI: 10.1016/j.envpol.2010.09.033

$228 \mathrm{CO}_{2} \cdot \mathrm{mg}^{-1} \mathrm{AFDW} \cdot \mathrm{h}^{-1}$. In addition to the SIR measurements, the basal respiration (without 229 substrate addition) was measured for each biofilm.

\section{Biofilm DNA extraction, amplification and automated ribosomal intergenic spacer} analysis (ARISA)

To characterize the diversity of the river biofilm bacterial communities, we used the ARISA molecular fingerprint technique. Three replicates of $2 \mathrm{~mL}$ of each biofilm suspension were centrifuged at 14,000g for 30 minutes, and the supernatant was discarded and pellet stored at $-80{ }^{\circ} \mathrm{C}$ before extraction. Nucleic acid extraction was performed on biofilm pellets using the FAST DNA kit (QBIOgene, Illkirch, France) according to the manufacturer's instructions.

The PCR conditions and the PCR template preparation for the ARISA conditions were those described by Ranjard et al. (2003). The primers used were S-D-Bact-1522-b-S-20 (3'end of 16S genes) and L-D-Bact-132-a-A-18 (5'end of 23S genes) (Ranajard et al., 2003).

\section{Data treatment}

$\mathrm{EC}_{50}$ values were calculated using the Regtox model

(E. Vindimian,

http://eric.vindimian.9online.fr/). The CLPP data sets (normalized by the basal respiration values) were subjected to principal component analysis (PCA) (XLSTAT Software Package. 2009 version). The significant level was set to $5 \%$ for all the statistical tests with four replicates for each parameter. Bacterial ARISA profiles were compared with regards to the presence or absence of bands, using the Pearson similarity index. Matrices were used to perform Ward's method of hierarchical cluster analysis (HCA) using the XLSTAT Software Package (2009 version).

\section{Results and discussion}

\section{MicroResp ${ }^{\mathrm{TM}}$ protocol applied to ecotoxicological bioassays on microbial biofilms}

251 In toxicological bioassays, adding a mineralizable carbon source overcomes a problem that 252 arises when measuring basal respiration, namely mineralization of unknown native organic 


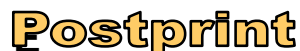

Version définitive du manuscrit publié dans / Final version of the manuscript published in : Environmental Pollution, 2011, Vol.159, no.1, 18-24, DOI: 10.1016/j.envpol.2010.09.033

matter that may be different between sampling stations. Glucose mineralization activity was detected by our MicroResp ${ }^{\mathrm{TM}}$ modified design within $8 \mathrm{~h}$ incubation time, and net $\mathrm{CO}_{2}$ production was approximately linear between $8 \mathrm{~h}$ and $15 \mathrm{~h}$ incubation time, with respiration rates of $160.0 \pm 14.9$ and $160.6 \pm 12.1 \mu \mathrm{g} \mathrm{CO} 2 . \mathrm{mg}^{-1} \mathrm{AFDW} \cdot \mathrm{h}^{-1}$ for $8 \mathrm{~h}$ and $15 \mathrm{~h}$ incubation time respectively. In addition, analysis of the bacterial community profiles (ARISA) of each of the four incubation times tested showed no change in the diversity of this community (data not shown). Incubation for $8 \mathrm{~h}$ would have sufficed, but for practical reasons we opted to conduct our bioassays with an incubation time of $15 \mathrm{~h}$ (overnight).

During preliminary bioassays with $\mathrm{Cu}$, no dose-response curves were obtained (data not shown). The quantities of measured $\mathrm{CO}_{2}$ corresponding to the well containing the most concentrated $\mathrm{Cu}$ solutions were high. The $\mathrm{pH}$ measurement of these biofilm solutions showed that the addition of large amounts of $\mathrm{Cu}$ to the biofilm suspensions induced a very rapid and marked $\mathrm{pH}$ decrease, linked to an abundant release of $\mathrm{CO}_{2}$, which could not be of biological origin but was probably due to chemical reactions. Oren and Steinberger (2008) suggested that dissolution of $\mathrm{CaCO}_{3}$ (contained in the biological samples, in their case soil) may follow $\mathrm{pH}$ decline, and be accompanied by abiotic $\mathrm{CO}_{2}$ evolution that may be mistakenly taken for respired $\mathrm{CO}_{2}$. Fig. 1 shows that $3 \mathrm{~h}$ of copper pre-incubation is needed to obtain a doseresponse curve and a percentage SIR inhibition below 20\% (19.01 $\pm 0.1 \%)$ with the maximum copper concentration $\left(17.2 \times 10^{2} \mu \mathrm{M}\right)$. This dose-response curve did not change with biofilms pre-incubated for longer times $(4 \mathrm{~h}$ and $6 \mathrm{~h})$. These results suggest that this chemical artefact has ceased after $3 \mathrm{~h}$. We therefore opted for this time of $3 \mathrm{~h}$ pre-incubation with copper.

Fig.1.

Finally, the protocol used for short-term bioassays can be summarized as follows: the biofilm suspension was distributed in deep wells (500 $\mu \mathrm{L}$ per well), to which we added $50 \mu \mathrm{L}$ of the metal solution (increasing nominal concentrations). The microplate was then pre-incubated in the dark at room temperature for $3 \mathrm{~h}, 30 \mu \mathrm{L}$ of the glucose solution $\left(120 \mathrm{mg} \cdot \mathrm{mL}^{-1}\right)$ was added 


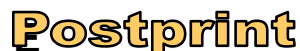

Version définitive du manuscrit publié dans / Final version of the manuscript published in : Environmental Pollution, 2011, Vol.159, no.1, 18-24, DOI: 10.1016/j.envpol.2010.09.033

279 to each well and the detection microplate was positioned. The system was sealed and 280 incubated for $15 \mathrm{~h}$ in the dark (without photosynthetic activity, which could induce an increase of the $\mathrm{pH}$ and interfere with the $\mathrm{CO}_{2}$ release) and at room temperature $\left(23 \pm 1^{\circ} \mathrm{C}\right)$.

$\mathrm{CO}_{2}$-trap absorbance was measured at $590 \mathrm{~nm}$ (or better at $570 \mathrm{~nm}$, Rowell, 1995) immediately before sealing to the deep well plate, and after $15 \mathrm{~h}$ incubation.

The MicroResp ${ }^{\mathrm{TM}}$ technique enabled us to plot dose-response curves with all the tested metals. The $\mathrm{EC}_{50}$ obtained with the different tested metals in short-term bioassays are shown in Table.3. Compared with the other metals, silver seems to be the most toxic metal to the SIR $\left(\mathrm{EC}_{50}=3.96 \mu \mathrm{M}\right)$. Aluminium $\left(\mathrm{EC}_{50}=2317.86 \mu \mathrm{M}\right)$ and cobalt $\left(\mathrm{EC}_{50}=6170.63 \mu \mathrm{M}\right)$ were the least toxic, while $\mathrm{Zn}, \mathrm{Cu}$ and $\mathrm{Cd}$ had similar intermediate toxicities. However, in our study some of the metal salts used included a nitrogen source (e.g. $\mathrm{AgNO}_{3} ; \mathrm{N}_{2} \mathrm{NiO}_{6} \cdot 6 \mathrm{H}_{2} \mathrm{O}$ or $\mathrm{CoN}_{2} \mathrm{O}_{6} \cdot 6 \mathrm{H}_{2} \mathrm{O}$ ) that could interfere with the respiration measurements and so bias the $\mathrm{EC}_{50}$ values. A second control using $\mathrm{NaNO}_{3}$ in addition to glucose might be a good option to overcome this interference. Witter et al., (2000) obtained similar results when testing soil bacteria tolerance (based on SIR) to these three metals (e.g. $\mathrm{EC}_{50} \mathrm{Zn}$ value of about $250 \mathrm{ppm}$ ).

$\mathrm{EC}_{50}$ values calculated for the percentage of 95 substrates used completely within 8 days of incubation in $\mathrm{Cu}(0-300 \mathrm{mM})$-amended BIOLOG GN plates inoculated with a river biofilm bacteria consortium were in the range 10-30 $\mu \mathrm{M}$ (Barranguet et al. 2003). Sensitivities obtained with other bioassays such as the well-known Microtox ${ }^{\circledR}$ (based on bioluminescence reduction of the marine bacterium Vibrio fischeri) are also comparable to our range of $\mathrm{EC}_{50}$ values $\left(\right.$ e.g. $\mathrm{EC}_{50}(5 \mathrm{mn})=941 \mu \mathrm{M} \mathrm{CdCl}_{2}$ and $168 \mu \mathrm{M} \mathrm{CuCl}_{2}$ and $\mathrm{EC}_{50}(15 \mathrm{mn})=421 \mu \mathrm{M}$ $\mathrm{CdCl}_{2}$ and $49 \mu \mathrm{M} \mathrm{CuCl}_{2}$, in Macken et al. 2009). Therefore, our dose-response curves and $\mathrm{EC}_{50}$ obtained with the SIR, related to heterotrophic organisms, confirm that the MicroResp ${ }^{\mathrm{TM}}$ technique could be a useful method to classify heavy metals according to their toxicity toward 303 river biofilms.

\section{Table.4.}




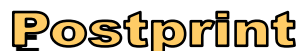

Version définitive du manuscrit publié dans / Final version of the manuscript published in : Environmental Pollution, 2011, Vol.159, no.1, 18-24, DOI: 10.1016/j.envpol.2010.09.033

\section{Application of the microrespirometry method to a field situation}

\subsection{Copper-induced tolerance}

$\mathrm{Cu} \mathrm{EC}_{50}$ values were estimated to evaluate tolerance to this pollutant of the biofilm communities sampled at three sites along the River Morcille. $\mathrm{EC}_{50}$ values increased upstream to downstream, ranging from 48.5 to $179.4 \mu \mathrm{M}$ copper (Table.3, Fig.2). The most $\mathrm{Cu}$ sensitive communities were from the upstream site "Saint-Joseph" (J), while the most $\mathbf{C u}$ tolerant communities were downstream at "Saint-Ennemond" $(\mathbf{E})$. The measured sensitivity at the intermediate site "Les Versauds" (V) was closer to $\mathbf{E}$ than to $\mathbf{J}$. $\mathbf{C u}$ concentrations in the water from the three sampling sites, collected in the same period as our study, and the $\mathrm{EC}_{50}$ values measured were closely correlated $\left(n=4\right.$, Pearson $\left.R^{2}=0.72, p=0.0004\right)$. Also, diversity analysis by ARISA of bacterial communities showed a differentiation of $\mathbf{J}, \mathbf{E}$ and $\mathbf{V}$. Bacterial diversity from the intermediate site $\mathbf{V}$ was more closely similar to the most contaminated site $\mathbf{E}$ than the pristine area $\mathbf{J}$ (Fig.3). These results agree with previous studies (Boivin et al., 2006; Dorigo et al., 2007) and are congruent with the predictions of the PICT concept and validation (Blanck, 2002), suggesting that $\mathrm{Cu}$ constitutes a selective pressure, at toxicants. During long-term exposure, for example, Guasch et al. (2004) and Tlili et al. (2010) showed that phosphorus supply caused an increased induced tolerance of biofilms to copper. Also, Guasch et al. (2002) evaluated the effects of chronic copper exposure on natural periphyton in a non-polluted calcareous river, and they concluded that the water $\mathrm{pH}$ in the river was important in affecting the bioavailability of the metals and therefore their toxicity towards the biological community. It is therefore necessary to have not only a reference site that is globally comparable to the study site, but also a sampling strategy (spatial and temporal) that minimizes the interference of environmental factors in the detection of PICT (Dorigo et al., 2009). Care must also be taken in a PICT approach to ascertain that bioassays 


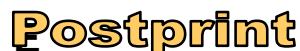

Version définitive du manuscrit publié dans / Final version of the manuscript published in : Environmental Pollution, 2011, Vol.159, no.1, 18-24, DOI: 10.1016/j.envpol.2010.09.033

are controlled and standardized, and that different physicochemical parameters are homogeneous and similar during short-term exposure of the tested communities. Blanck (2002) stipulated that bioavailability may interfere in the PICT detection as a confounding factor, for example when the waters used in the short-term tests are different. This could then affect the $\mathrm{EC}_{\mathrm{X}}$ values obtained and finally the PICT signal may represent a bioavailability gradient. However, this remark concerns a regional survey (Blanck et al., 2003) that compared very different sampling sites (from different rivers and countries) in the context of bioassays that used the filtered natural water from each sampling area. This was not the case in our study, where we used the same filtered water of the upstream sampling area $\mathbf{J}$ ( $\mathrm{pH}$ values in the range 7.2-8) for periphytic suspensions and toxic solutions of all bioassays and in the context of a small river basin. In addition, in a previous study we measured $\mathrm{pH}$ in the biofilmriver suspension (using water from site $\mathbf{J}$ ), glucose and copper added at the beginning and end of the short-term incubation, and observed no $\mathrm{pH}$ changes during the bioassays despite demonstrating an induced tolerance to copper based on the substrate-induced respiration as a functional parameter (measured by gas chromatography, data not shown). Rusk et al. (2004) investigated tolerance of soil biological nitrification to metals using sterilized, metal-treated soils from the reference area reinoculated with a similar soil containing the microbial communities to be tested. Our approach using filtered water from a reference area (upstream) to perform the PICT bioassays, in which we suspended periphyton scraped from the different investigated sites, is comparable to the approach of Rusk et al. (2004), who wanted to exclude the potentially confounding effects of variations in metal bioavailability in their tolerance bioassays. We can conclude that the bioassays conducted during our study were performed under homogeneous standardized conditions and minimized variations in metal bioavailability among the microbial samples tested.

Table.4. Fig.2. Fig.3. 


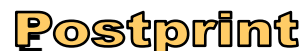

Version définitive du manuscrit publié dans / Final version of the manuscript published in : Environmental Pollution, 2011, Vol.159, no.1, 18-24, DOI: 10.1016/j.envpol.2010.09.033

361 In previous studies, a respirometric technique based on the analysis of the substrate-induced 362 respiration (SIR) response was developed to test the microbial tolerance to toxicants at the community level in soil ecosystems (Witter et al., 2000). These studies demonstrated that microbial tolerance to metals increased as soil metal pollutant concentrations increased. However, there are few studies on the toxicity assessment of contaminants in aquatic ecosystems using the SIR to assess the induced tolerance to metals of heterotrophic biofilm communities. Dorigo et al. (2010), investigated the effects of $\mathrm{Cu}$ on heterotrophic biofilm communities collected from the same sampling sites $(\mathbf{J} ; \mathbf{V}$ and $\mathbf{E})$, using the SIR measured by gas chromatography and the 16S rRNA gene DGGE method to highlight induced tolerance to $\mathrm{Cu}$ and bacterial diversity respectively. Like ours, her results strongly suggested $\mathrm{Cu}$ contamination-driven changes in biofilm community structure and in the tolerance to $\mathrm{Cu}$ of the bacterial community, confirming the PICT hypothesis.

This first biofilm ecotoxicological bioassays using MicroResp ${ }^{\text {TM }}$ applied in a river contamination assessment context, highlights the efficiency of this technique for measuring the induced tolerance to metals of the heterotrophic biofilm community based on SIR.

\subsection{Co-tolerance assessment}

Co-tolerance may occur when communities that have been exposed to one toxicant, but not to another, become tolerant to both toxicants. Occurrence of co-tolerance depends on the means of conferring tolerance and on the tolerance mechanisms (Blanck et al., 1988). Tolerance to $\mathrm{Ag}$ and $\mathrm{Cd}$ was measured for biofilms from the three sampling sites (J, V and E) (Table.3). In contrast to results for copper, no significant changes in tolerance to $\mathrm{Ag}$ or $\mathrm{Cd}$ were observed from upstream to downstream sites. These results are congruent with $\mathrm{Ag}$ and $\mathrm{Cd}$ concentrations measured in water from $\mathbf{J}, \mathbf{V}$ and $\mathbf{E}$ sites, which were constantly below the limits of quantification. Therefore, these SIR measurements with MicroResp ${ }^{\mathrm{TM}}$ did not reveal any co-tolerance between $\mathrm{Cu}$ and $\mathrm{Ag}$ or $\mathrm{Cd}$. Some studies have reported a co-tolerance of biofilm communities between copper and some metals such as $\mathrm{Zn}$ or Ni (Gustavson and 


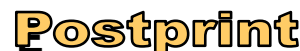

Version définitive du manuscrit publié dans / Final version of the manuscript published in : Environmental Pollution, 2011, Vol.159, no.1, 18-24, DOI: 10.1016/j.envpol.2010.09.033

Wängberg, 1995; Ivorra et al., 1999). Soldo and Behra (2000) have shown a strong cotolerance to silver in autotrophic biofilm communities exposed to $5 \mu \mathrm{M}$ of copper. In contrast to our study, all these co-tolerance measurements were based on photosynthetic activity, and therefore especially targeted the phototrophic biofilm compartment. Detection of co-tolerance implies difficulty attributing a tolerance shift to the presence of a particular toxicant in the environment. Our results and those obtained in the above-cited studies show that depending on the kind of targeted activities and associated communities (phototrophic or heterotrophic), co-tolerance linked to specific modes of action of toxicants and detoxification processes (Soldo and Behra, 2000; Knauer et al., 2010) can be variable. MicroResp ${ }^{\mathrm{TM}}$ use, in addition to other tolerance measurements based on other activities in the context of co-tolerance studies, could thus offer a complementary approach to investigating mechanisms of tolerance.

\subsection{Community-level physiological profiles}

Principal component analysis (PCA) was applied to the data set obtained with the various carbon sources, normalized by the basal respiration values for each site (Fig.4). The first two axes of the PCA accounted for more than $80 \%$ of the variability. Pristine area $\mathbf{J}$ and downstream area $\mathbf{E}$ were separated from the intermediate area $\mathbf{V}$ on the first axis F1, while the second axis F2 separated area $\mathbf{J}$ from area $\mathbf{E}$ (left panel). Biofilms from $\mathbf{V}$ were characterized by a higher mineralization of the glutamic acid and citric acid substrate and biofilms from $\mathbf{J}$ and $\mathbf{E}$ were characterized by a higher mineralization rate of glucose substrate (right panel). Thus multivariate analysis showed a clear discrimination between the biofilms from the different sampling sites. Several soil studies investigated functional diversity with CLPP measurements and showed the utility of the MicroResp ${ }^{\mathrm{TM}}$ method to discriminate different soils or soils submitted to different pressures (Campbell et al., 2003, 2008; Oren and Stenberger, 2008). Applied to an aquatic environment, MicroResp ${ }^{\mathrm{TM}}$ seems also to be a useful tool for assessing changes in the functional diversity of the microbial community (CLPPs) in biofilms. 


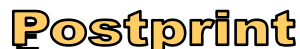

Version définitive du manuscrit publié dans / Final version of the manuscript published in : Environmental Pollution, 2011, Vol.159, no.1, 18-24, DOI: 10.1016/j.envpol.2010.09.033

413 Fig.4.

\section{Conclusion and perspectives}

In the global context of assessing the impact of pollutants on the diversity and functioning of microbial communities in aquatic ecosystems, a range of diversified indicators for diversified functions and communities is needed (Clements and Rohr, 2009). Among such indicators, the PICT approach, which offers a good tool for assessing an ecosystem's history of exposure to pollution at the community level, and the establishment of catabolic fingerprint profiles of microbial communities, are now applied in diverse ecosystems (Bérard et al., 2002; Boivin et al., 2006; Kaufmann et al., 2006). However, this study is the first to investigate micro-SIR in a contaminated aquatic system as a tool for measuring induced tolerance in a microbial community and establishing catabolic physiological profiles on the whole heterotrophic biofilm. The purpose of this methodological study was not to make a direct translation of the $\mathrm{EC}_{50}$ obtained in MicroResp ${ }^{\mathrm{TM}}$ plates to the situation of the biofilms exposed in the river, but to propose an easy short-term bioassay based on catabolism to detect relative differences in metal tolerance between long-term exposed communities that were sampled (complementary to investigations of their taxonomic composition for PICT methodology). Our results show that the MicroResp ${ }^{\mathrm{TM}}$ technique offers a convenient, rapid and sensitive method for assessing metal contamination of aquatic ecosystems. Like for soil microbial micro-SIR measurements, for results to be fully transportable between studies, this method would require interlaboratory calibration (Creamer et al., 2009). A modified MicroResp ${ }^{\text {TM }}$ system could be developed, using microplates with larger wells than those currently used. The method could thus be applied with an in-place biofilm (grown on individual artificial substrates) to minimize disturbances of the microbial communities and be suitable for similar samples of periphyton, and for other measurements of additional activities such as photosynthesis (Dorigo and Leboulanger, 2001). 


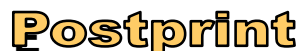

Version définitive du manuscrit publié dans / Final version of the manuscript published in : Environmental Pollution, 2011, Vol.159, no.1, 18-24, DOI: 10.1016/j.envpol.2010.09.033

\section{Acknowledgments}

The authors thank G. Sevenier (UMR EMMAH, INRA-UAPV, France) for technical advice on the MicroResp ${ }^{\mathrm{TM}}$ technique, M. Coquery, J. Gahou for metal analysis, B. Motte (UR MAEP, CEMAGREF-Lyon, France) for field sampling and ATT for editing the Englishlanguage version of the manuscript. We thank Onema (French National Agency for Water and Aquatic Ecosystems) for financial support (Program 26 “Assessment and Remediation of Pesticide Effects").

\section{References}

Barranguet, C., Van Den Ende, F.P., Rutgers, M., Breure, A.M., Greijdanus, M., Sinke, J.J., Admiraal, W., 2003. Copper-induced modifications of the trophic relations in riverine algalbacterial biofilms. Environmental Toxicology and Chemistry. 22, (6) 1340-1349.

Battin, T.J., Kaplan, L.A., Newbold, J.D., Hansen, C.M.E., 2003. Contributions of microbial biofilms to ecosystem processes in stream mesocosms. Nature. 426, (6965) 439-442.

Bérard, A., Dorigo, U., Humbert, J.F., Leboulanger, C., Seguin, F., 2002. Application of the Pollution-Induced Community Tolerance (PICT) method to algal communities: its values as a diagnostic tool for ecotoxicological risk assessment in the aquatic environment. Annls Limnol- I. J. Limnol. 38, (3) 247-261.

Blanck, H., Wänkberg, S.-Å., Molander, S., 1988. Pollution-Induced Community Tolerance A new ecotoxicological tool, in: Cairs, J., Jr.,Pratt, J.R. (Eds.), Functional testing of aquatic biota for estimating hazards of chemicals. ASTM STP 988, Philadelphia, pp. 219-230.

Blanck, H., Admiraal, W., Cleven, R.F.M.J., Guasch, H., Van Den Hoop, M.A.G.T., Ivorra, N., Nystrom, B., Paulsson, M., Petterson, R.P., Sabater, S., Tubbing, G.M.J., 2003. Variability in zinc tolerance, measured as incorporation of radio-labeled carbon dioxide and thymidine, in periphyton communities sampled from 15 European river stretches. Arch. Environ. Contam. Toxicol. 44, 17-29. 


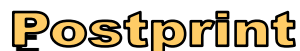

Version définitive du manuscrit publié dans / Final version of the manuscript published in : Environmental Pollution, 2011, Vol.159, no.1, 18-24, DOI: 10.1016/j.envpol.2010.09.033

Boivin, M.E.Y., Massieux, B., Breure, A.M., Greve, G.D., Rutgers, M., Admiraal, W., 2006. Functional recovery of biofilm bacterial communities after copper exposure. Environmental Pollution. 140, (2) 239-246.

Campbell, C.D., Chapman, S.J., Cameron, C.M., Davidson, M.S., Potts, J.M., 2003. A rapid microtiter plate method to measure carbon dioxide evolved from carbon substrate amendments so as to determine the physiological profiles of soil microbial communities by using whole soil. Applied and Environmental Microbiology. 69, (6) 3593-3599.

Campbell, C.D., Cameron, C.M., Bastias, B.A., Chen, C.R., Cairney, J.W.G., 2008. Long term repeated burning in a wet sclerophyll forest reduces fungal and bacterial biomass and responses to carbon substrates. Soil Biology \& Biochemistry. 40, (9) 2246-2252.

Chapman, S.J., Campbell, C.D., Artz, R.R.E., 2007. Assessing CLPPs using MicroResp ${ }^{\mathrm{TM}}$ - A comparison with biolog and multi-SIR. Journal of Soils and Sediments. 7, (6) 406-410.

Clements, W.H., Rohr, J.R., 2009. Community Responses to Contaminants: Using Basic Ecological Principles to Predict Ecotoxicological Effects. Environmental Toxicology and Chemistry. 28, (9) 1789-1800.

Creamer, R.E., Bellamy, P., Black, H.I.J., Cameron, C.M., Campbell, C.D., Chamberlain, P., Harris, J., Parekh, N., Pawlett, M., Poskitt, J., Stone, D., Ritz, K., 2009. An inter-laboratory comparison of multi-enzyme and multiple substrate-induced respiration assays to assess method consistency in soil monitoring. Biology and Fertility of Soils. 45, (6) 623-633.

Diaz-Ravina, M., Calvo De Anta, R., Baath, E., 2007. Tolerance (PICT) of the Bacterial Communities to Copper in Vineyards Soils from Spain. J. Environ. Qual. 36, 1760-1764.

Dorigo, U., Leboulanger, C., 2001. A PAM fluorescence-based method for assessing the effects of photosystem II herbicides on freshwater periphyton. Journal of Applied Phycology. 13, (6) 509-515. 


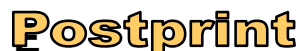

Version définitive du manuscrit publié dans / Final version of the manuscript published in : Environmental Pollution, 2011, Vol.159, no.1, 18-24, DOI: 10.1016/j.envpol.2010.09.033

Dorigo, U., Bourrain, X., A., B., Leboulanger, C., 2003. Seasonal changes in river microalgae sensitivity to atrazine and isoproturon, along a contamination gradient. The Science of the Total Environment. 318, 101-114.

Dorigo, U., Leboulanger, C., Bérard, A., Bouchez, A., Humbert, J.F., Montuelle, B., 2007. Lotic biofilm community structure and pesticide tolerance along a contamination gradient in a vineyard area. Aquatic Microbial Ecology. 50, (1) 91-102.

Dorigo, U., Lefranc, M., Leboulanger, C., Montuelle, B., Humbert, JF., 2009, Influence of sampling strategy on the assessment of the impact of pesticides on periphytic microbial communities in a small river. FEMS Microbial Ecology, 67, 491-501.

Dorigo, U., Berard, A., Rimet, F., Bouchez, A., Montuelle, B., 2010. In situ assessment of periphyton recovery in a river contaminated by pesticides. Aquatic Toxicology. 98, (4) 396406.

Garland, J.L., Mills, A.L., 1991. Classification and Characterization of Heterotrophic Microbial Communities on the Basis of Patterns of Community-Level Sole-Carbon-Source Utilization. Applied and Environmental Microbiology. 57, (8) 2351-2359.

Guasch, H., Paulsson, M., Sabater, S., 2002. Effect of copper on algal communities from oligotrophic calcareous streams. Journal of Phycology. 38, (2) 241-248.

Guasch, H., Navarro, E., Serra, A., Sabater, S., 2004. Phosphate limitation influences the sensitivity to copper in periphytic algae. Freshwater Biology. 49, (4) 463-473.

Gustavson, K., Wängberg, S.-Å. 1995. Tolerance induction and succession in microalgae communities exposed to copper and atrazine. Aquatic Toxicology. 32, 283-302.

Ivorra, N., Hettelaar, J., Tubbing, G.M.J., Kraak, M.H.S., abater, S., Admiraal, W., 1999. Translocation of microbenthic algal assemblages used for in-situ analysis of metal pollution in rivers. Arch. Environ. Contam. Toxicol. 37, 19-28.Kaufmann, K., Chapman, S.J., 


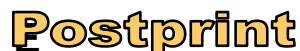

Version définitive du manuscrit publié dans / Final version of the manuscript published in : Environmental Pollution, 2011, Vol.159, no.1, 18-24, DOI: 10.1016/j.envpol.2010.09.033

511 Kaufmann, K., Chapman, S.J., Campbell, C.D., Harms, H., Hohener, P., 2006. Miniaturized test system for soil respiration induced by volatile pollutants. Environmental Pollution. 140, (2) $269-278$.

Knauer, K., Leimgruber, A., Hommen, U., Knauert, S., 2010. Co-tolerance of phytoplankton communities to photosynthesis II inhibitors. Aquatic Toxicology. 96, (4) 256-263.

Lesley, A., Ogilvie, A.B., Alistair Grant, B., 2008. Linking pollution induced community tolerance (PICT) and microbial community structure in chronically metal polluted estuarine sediments. Marine Environmental Research. 65, 187-198.

Lindsay, W.L., 1979. Carbonate equilibria, in: Lindsay, W.L. (Eds.), Chemical Equilibria in Soils. Wiley, M. J, New York, pp. 78-84.

Macken, A., Giltrap, M., Ryall, K., Foley, B., Mcgovern, E., Mchugh, B., Davoren, M., 2009. A test battery approach to the ecotoxicological evaluation of cadmium and copper employing a battery of marine bioassays. Ecotoxicology. 18, (4) 470-480.

Montuelle, B., Dorigo, U., Bérard, A., Bouchez, A., Tlili, A., Gouy, V., Pesce, S., 2010. The periphyton as a multimetric bioindicator to assess the impact of land use on river: an overview on the Ardières-Morcille experimental watershed (France). Hydribiologia. inpress,

Morin, S., Pesce, S., Tlili, A., Coste, M., Montuelle, B., 2010. Recovery potential of periphytic communities in a river impacted by a vineyard watershed. Ecological Indicators. $10,(2) 419-426$.

Oren, A., Steinberger, Y., 2008. Coping with artifacts induced by CaCO3-CO2-H2O equilibria in substrate utilization profiling of calcareous soils. Soil Biology \& Biochemistry. $40,(10) 2569-2577$.

Paulsson, M., Nystrom, B., Blanck, H., 2000. Long-term toxicity of zinc to bacteria and algae in periphyton communities from the river Gota Alv, based on a microcosm study. Aquatic Toxicology. 47, (3-4) 243-257. 


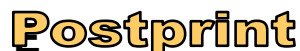

Version définitive du manuscrit publié dans / Final version of the manuscript published in : Environmental Pollution, 2011, Vol.159, no.1, 18-24, DOI: 10.1016/j.envpol.2010.09.033

536

537

Preston-Mafham, J., Boddy, L., Randerson, P.F., 2002. Analysis of microbial community functional diversity using sole-carbon-source utilisation profiles - a critique. Fems Microbiology Ecology. 42, (1) 1-14.

Rabiet, M., Margoum, C., Gouy, V., Carluer, N., Coquery, M.. . 2008. Transfert des pesticides dans un petit bassin versant viticole. Influence des conditions hydrologiques sur le transport de ces contaminants. Ingénieuries EAT.

Rajapaksha, R.M.C.P., Tobor-Kaplon, M.A., Baath, E., 2004. Metal toxicity affects fungal and bacterial activities in soil differently. Applied and Environmental Microbiology. 70, (5) 2966-2973.

Ranjard, L., Lejon, D.P.H., Mougel, C., Schehrer, L., Merdinoglu, D., Chaussod, R., 2003. Sampling strategy in molecular microbial ecology: influence of soil sample size on DNA fingerprinting analysis of fungal and bacterial communities. Environmental Microbiology. 5, (11) 1111-1120.

Rusk, J.A., Hamon, R.E., Stevens, D.P., Mclaughlin, M.J., 2004. Adaptation of soil biological nitrification to heavy metals. Environmental Science \& Technology. 38, (11) 3092-3097.

Soldo, D., Behra, R., 2000. Long-term effects of copper on the structure of freshwater periphyton communities and their tolerance to copper, zinc, nickel and silver. Aquatic Toxicology. 47, (3-4) 181-189.

Stefanowicz, A.M., Niklinska, M., Laskowski, R., 2009. Pollution-induced tolerance of soil bacterial communities in meadow and forest ecosystems polluted with heavy metals. European Journal of Soil Biology. 45, (4) 363-369.

Tlili, A., Dorigo, U., Montuelle, B., Margoum, C., Carluer, N., Gouy, V., Bouchez, A.,Bérard, A., 2008. Responses of chronically contaminated biofilms to short pulses of diuron - An experimental study simulating flooding events in a small river. Aquatic Toxicology. 87, (4) 252-263. 


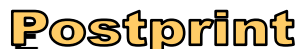

Version définitive du manuscrit publié dans / Final version of the manuscript published in : Environmental Pollution, 2011, Vol.159, no.1, 18-24, DOI: 10.1016/j.envpol.2010.09.033

561 Tlili, A., Bérard, A., Roulier, J.L., Volat, B., Montuelle, B., 2010. $\mathrm{PO}_{4}{ }^{3-}$ dependence of 562 biofilm autotrophic and heterotrophic communities tolerance to copper and diuron. Aquatic Toxicology. 98, (2) 165-177.

Witter, E., Gong, P., Baath, E., Marstorp, H., 2000. A study of the structure and metal tolerance of the soil microbial community six years after cessation of sewage sludge applications. Environmental Toxicology and Chemistry. 19, (8) 1983-1991. 


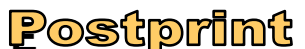

Version définitive du manuscrit publié dans / Final version of the manuscript published in : Environmental Pollution, 2011, Vol.159, no.1, 18-24, DOI: 10.1016/j.envpol.2010.09.033

587 Table.1. Means ( \pm standard deviation, $n=43$ ) of selected chemical parameters $(\mathrm{pH}$; cond.:

588 conductivity $\left[\mu \mathrm{S} . \mathrm{cm}^{-1}\right] ;$ DOC $\left[\mathrm{mg} \cdot \mathrm{L}^{-1}\right] ; \mathrm{NH}_{4}^{+}\left[\mathrm{mg} \cdot \mathrm{L}^{-1}\right] ; \mathrm{NO}_{2}^{-}\left[\mathrm{mg} \cdot \mathrm{L}^{-1}\right] ; \mathrm{NO}_{3}^{-}\left[\mathrm{mg} \cdot \mathrm{L}^{-1}\right]$ and $\left.\mathrm{PO}_{4}{ }^{3-}\left[\mathrm{mg} . \mathrm{L}^{-1}\right]\right)$ obtained from the three sampling areas (J: Saint-Joseph; V: Les Versauds and E: Saint-Ennemond) over two years (2009 and 2010).

\begin{tabular}{cccccccc}
\hline Site & $\mathbf{p H}$ & cond & $\mathbf{D O C}$ & $\mathbf{N H}_{\mathbf{4}}{ }^{+}$ & $\mathbf{N O}_{2}{ }^{-}$ & $\mathbf{N O}_{3}{ }^{-}$ & $\mathbf{P O}_{4}{ }^{3-}$ \\
\hline \multirow{2}{*}{$\mathbf{J}$} & 7.27 & 161.72 & 2.67 & 0.04 & 0.02 & 6.82 & 0.07 \\
& \pm 0.29 & \pm 17.65 & \pm 0.88 & \pm 0.03 & \pm 0.01 & \pm 1.28 & \pm 0.03 \\
$\mathbf{V}$ & 7.41 & 201.33 & 3.28 & 0.05 & 0.03 & 7.58 & 0.23 \\
& \pm 0.27 & \pm 18.57 & \pm 0.91 & \pm 0.04 & \pm 0.01 & \pm 3.03 & \pm 0.13 \\
$\mathbf{E}$ & 7.51 & 233.61 & 4.52 & 0.08 & 0.06 & 7.33 & 0.28 \\
& \pm 0.24 & \pm 33.52 & \pm 1.82 & \pm 0.04 & \pm 0.06 & \pm 2.69 & \pm 0.17 \\
\hline
\end{tabular}




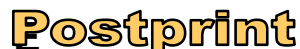

Version définitive du manuscrit publié dans / Final version of the manuscript published in : Environmental Pollution, 2011, Vol.159, no.1, 18-24, DOI: 10.1016/j.envpol.2010.09.033

610 Table. 2. Chronological summary of the different experiments and steps performed during the

611 study

\begin{tabular}{|c|c|c|}
\hline & Step No. & Biofilm used \\
\hline $\begin{array}{l}\text { Development of the } \\
\text { MicroResp }^{\mathrm{TM}} \\
\text { protocol, applied to } \\
\text { aquatic ecosystems } \\
\text { and using river } \\
\text { biofilms. }\end{array}$ & $\begin{array}{l}\text { 1. Incubation time } \\
\text { To ensure a relevant measure in the } \\
\text { well airspace of the } \mathrm{CO}_{2} \text { released from } \\
\text { the sample. } \\
\text { 2. Pre-incubation test with toxicant } \\
\text { To cope with artefacts causing a } \\
\text { chemical release of } \mathrm{CO}_{2} \text {. } \\
\text { 3. Short-term bioassays } \\
\text { To validate the utility of the } \\
\text { MicroResp } \\
\text { bM method for short-term } \\
\text { bioassays with different metals. }\end{array}$ & $\begin{array}{l}\text { Cultivated in } \\
\text { laboratory } \\
\text { microcosms under } \\
\text { controlled conditions }\end{array}$ \\
\hline Experiment 2 & $\begin{array}{l}\text { 1. PICT approach (short-term } \\
\text { bioassays) }\end{array}$ & $\begin{array}{l}\text { Collected from the } \\
\text { three sampling sites }\end{array}$ \\
\hline $\begin{array}{l}\text { Application of the } \\
\text { microrespirometric } \\
\text { method to a field } \\
\text { situation }\end{array}$ & $\begin{array}{l}\text { To validate the relevance of the } \\
\text { MicroResp }^{\mathrm{TM}} \text { technique in a PICT } \\
\text { approach, by testing copper, silver and } \\
\text { cadmium. } \\
\text { 2. Catabolic diversity fingerprint } \\
\text { To establish a CLPP of the } \\
\text { heterotrophic biofilm compartment, } \\
\text { using a multiple carbon-source } \\
\text { substrate. } \\
\text { 3. Molecular biology analysis } \\
\text { To characterize the diversity of the } \\
\text { river biofilm bacterial communities, } \\
\text { using the ARISA molecular fingerprint } \\
\text { technique. }\end{array}$ & in the Morcille River. \\
\hline
\end{tabular}




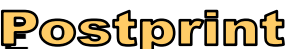

Version définitive du manuscrit publié dans / Final version of the manuscript published in : Environmental Pollution, 2011, Vol.159, no.1, 18-24, DOI: 10.1016/j.envpol.2010.09.033

615 Table. 3. Sensitivity (expressed as $\mathrm{EC}_{50}$ in $\mu \mathrm{M}$ ) of the heterotrophic biofilm community to 616 different tested metals in short-term bioassays using MicroResp ${ }^{\text {TM }}$. C.I. confidence interval $617(n=4 ; \alpha=0.5)$

\section{Tested metal $\mathrm{EC}_{50} \boldsymbol{\mu M} \quad$ C.I.}

Silver

Zinc

Copper

Cadmium

Arsenic

Nickel

Iron

Aluminium

Cobalt
3.96

82.41

$2.60-6.27$

156.45

194.95

$15.77-323.18$

244.46

$122.27-196.44$

$110.99-336.18$

403.53

$178.52-348.43$

772.88

$87.14-1184.89$

627

629

630

631

气 632

633

634

635

636

637

638

639

640

641

642

643

644

645 


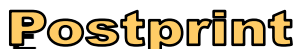

Version définitive du manuscrit publié dans / Final version of the manuscript published in : Environmental Pollution, 2011, Vol.159, no.1, 18-24, DOI: 10.1016/j.envpol.2010.09.033

646 Table. 4. $\mathrm{EC}_{50}$ values (in $\mu \mathrm{M}$ of copper, silver or cadmium) for the three sampling sites (J:

647 Saint-Joseph; V: Les Versauds; E: Saint-Ennemond). C.I. confidence interval $(n=4 ; \alpha=0.5)$.

\begin{tabular}{llcc}
\multicolumn{5}{l}{ Tested metal } & Site & $\mathrm{EC}_{50} \boldsymbol{\mu M}$ & C.I. \\
\cline { 2 - 4 } Copper & $\mathrm{J}$ & 48.52 & $41.02-59.13$ \\
& $\mathrm{~V}$ & 172.37 & $133.50-227.91$ \\
& $\mathrm{E}$ & 179.42 & $117.11-266.18$ \\
\hline \multirow{2}{*}{ Silver } & $\mathrm{J}$ & 31.99 & $25.99-40.67$ \\
& $\mathrm{~V}$ & 22.39 & $17.25-31.37$ \\
& $\mathrm{E}$ & 25.52 & $19.22-36.01$ \\
\hline \multirow{2}{*}{ Cadmium } & $\mathrm{J}$ & 82.48 & $65.59-103.61$ \\
& $\mathrm{~V}$ & 111.15 & $91.04-142.36$ \\
& $\mathrm{E}$ & 82.48 & $65.59-103.61$ \\
\hline
\end{tabular}

50

651

652

653

54 


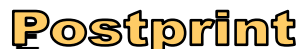

Version définitive du manuscrit publié dans / Final version of the manuscript published in : Environmental Pollution, 2011, Vol.159, no.1, 18-24, DOI: 10.1016/j.envpol.2010.09.033

Fig. 1. Respiration values (expressed as a percentage of control) after short-term bioassay with different pre-incubation periods

before addition of the carbon substrate (glucose). Error bars represent standard deviations ( $n=$ 4).

Fig. 2. Copper tolerance of heterotrophic communities at three sampling areas along a copper contamination gradient in the River Morcille. Symbols for each area $(\bullet$ : Saint-Joseph; $\mathbf{\bullet}$ : Les Versauds; $\mathbf{\Delta}$ : Saint-Ennemond), represent average SIR expressed as a percentage of the corresponding controls and obtained during the MicroResp ${ }^{\mathrm{TM}}$ short-term bioassay. Doseresponse curves $(\diamond$ : Saint-Joseph; $\square$ : Les Versauds; $\triangle$ : Saint-Ennemond) represent the Hill equation model applied to the same SIR measurements. Parameters were calculated by nonlinear regression and statistics (four replicates) were obtained using a Bootstrap-MonteCarlo simulation (from Regtox model).

Fig 3. Cluster analysis (hierarchical ascendant classification based on Pearson correlation coefficient) of the bacterial community (ARISA analysis of PCR amplified IGS gene fragments) from three sampling areas (J: Saint-Joseph; V: Les Versauds; E: Saint-Ennemond) on the River Morcille (three replicates per sampling area).

Fig 4. Principal component analysis (PCA) of community-level physiological profiles (CLPP) of biofilms measured with the MicroResp ${ }^{\mathrm{TM}}$ method and normalized to basal respiration, from three sampling areas (J: Saint-Joseph; V: Les Versauds; E: Saint-Ennemond) in the River Morcille (four replicates per sampling area). 
Fig.1

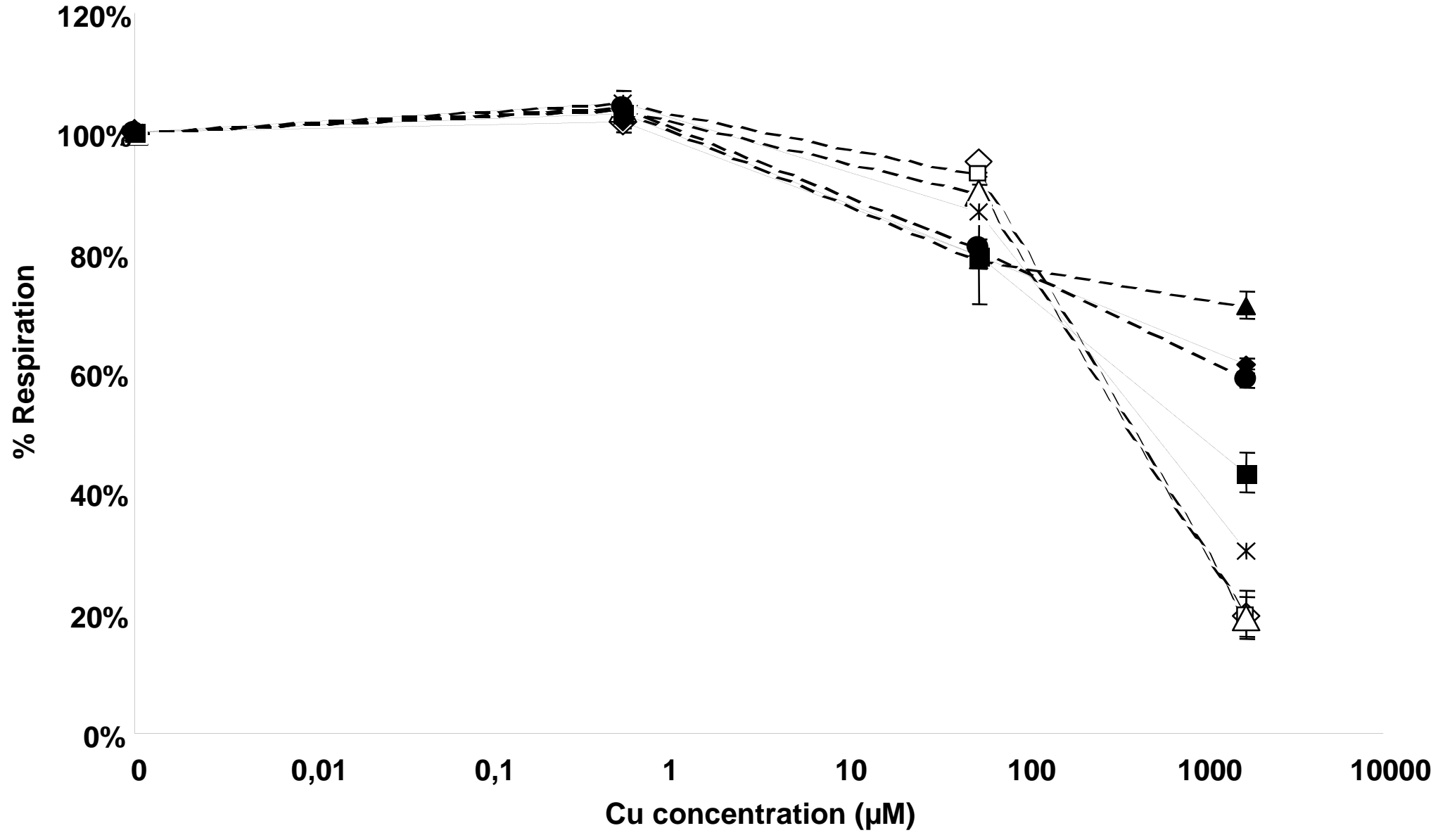




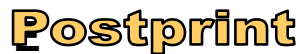

Version définitive du manuscrit publié dans / Final version of the manuscript published in : Environmental Pollution, 2011, Vol.159, no.1, 18-24, DOI: 10.1016/j.envpol.2010.09.033

\section{Fig.2}

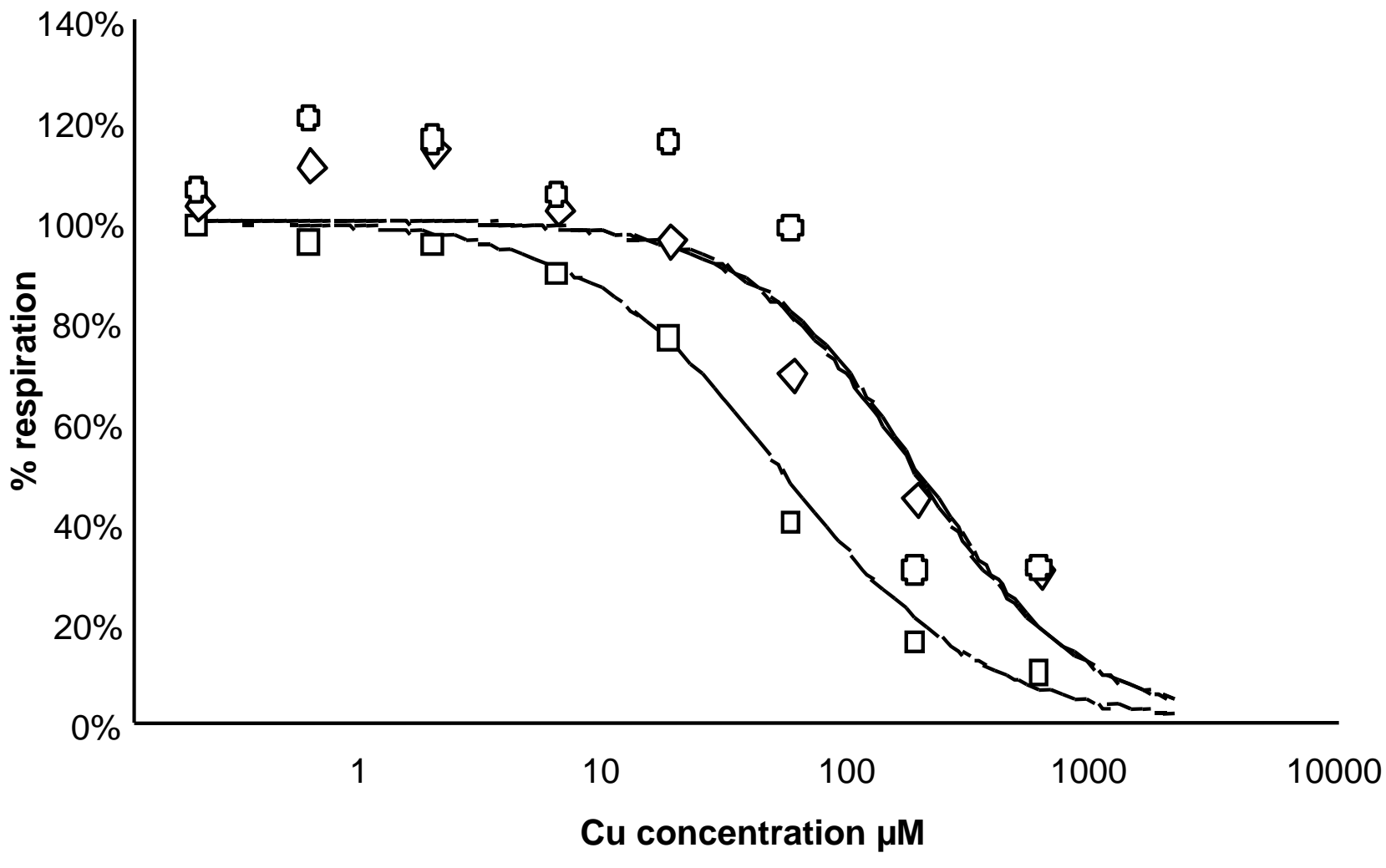




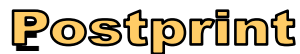

Version définitive du manuscrit publié dans / Final version of the manuscript published in : Environmental Pollution, 2011, Vol.159, no.1, 18-24, DOI: 10.1016/j.envpol.2010.09.033

\section{Fig.3}

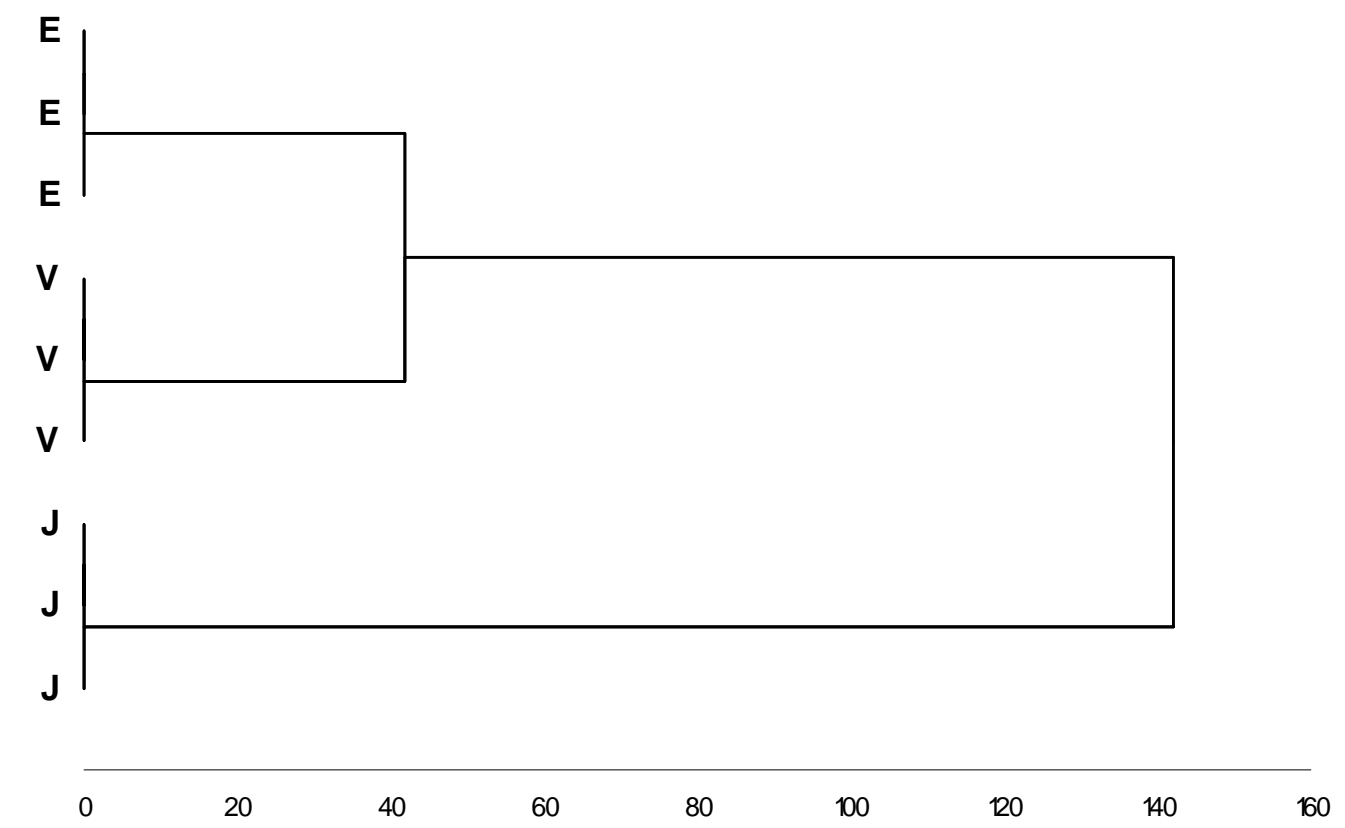




\section{Fig.4}
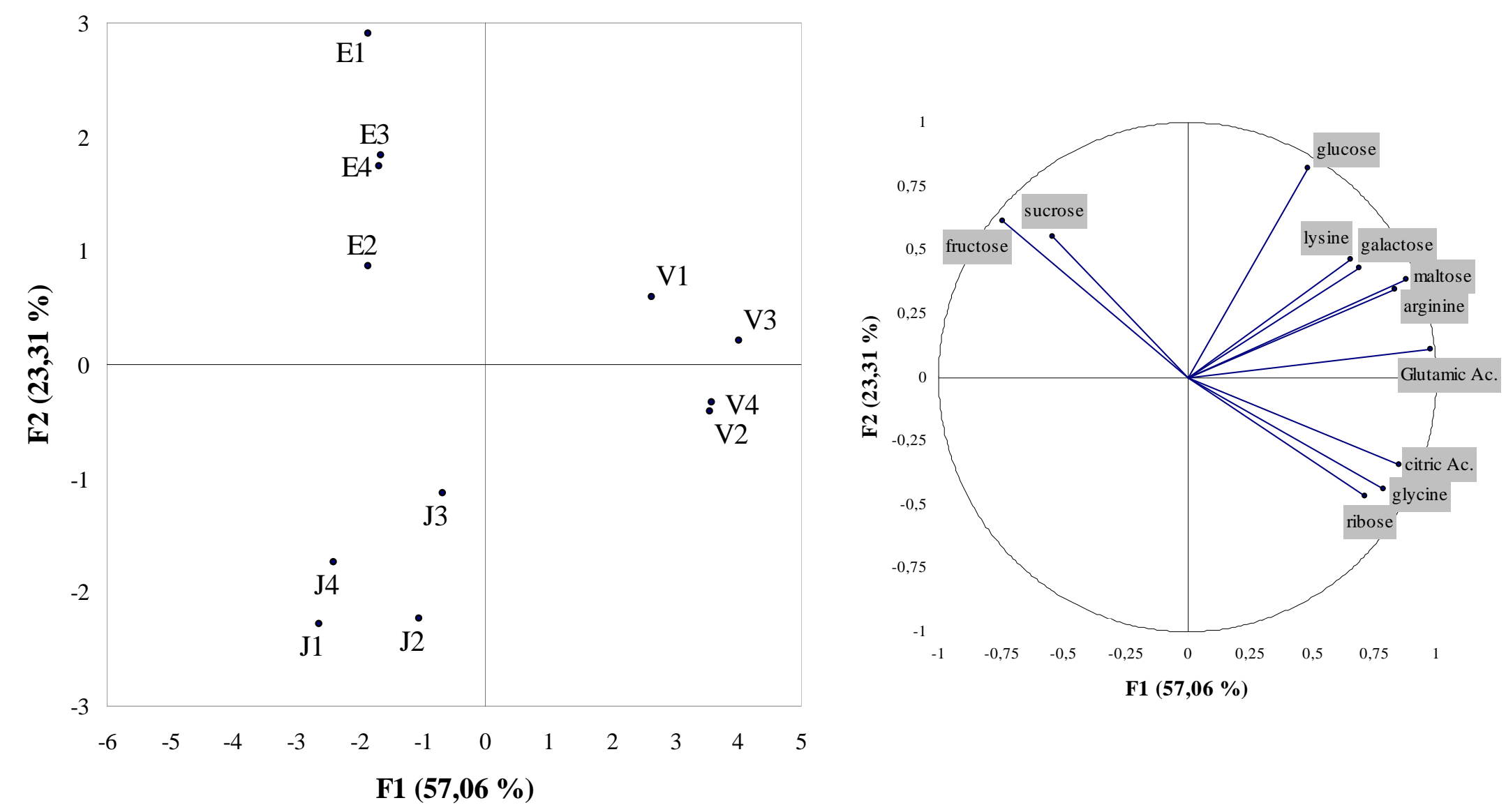